\title{
GLOBAL AESTHETICSCAPES: RE-IMAG(IN)ING THE GLOBAL EXPERIENCES OF SELECTED FILIPINO ARTISTS THROUGH THEIR INSTALLATION ARTWORKS
}

\author{
Clod Marlan Krister V. Yambao \\ Department of Art Studies \\ University of the Philippines \\ yayoo_com@yahoo.com
}

\begin{abstract}
This paper attempts to look at the contemporary global condition of Filipino art production by using the term "aestheticscapes"1 as a critical category of analysis. The confluence of the terms "aesthetics" and "-scapes" allows us to stretch the language of aesthetic production in a global scale of interactions, exchanges, contacts, circulations, negotiations, and amalgamations of geo and ethnoaesthetic positions. Significantly, "aestheticscapes" magnify the conditions of epistemic relations between global powers and discourses of the agencies of the artists via history, geography, aesthetic epistemes, and other social narratives. By looking at the installation artworks of selected Filipino diasporic, migrant, and mobile artists; this paper proposes that the conditions of global openness and mobility of ideas and people produce possibilities of reimagining and reworlding art history and art theory using the narrative of diasporic, migrant and mobile lives of artists and their works. This paper also suggests that aestheticscapes construct a platform of epistemic inquiry that fleshes out the different perspectival situatedness and conditions of aesthetic positions in global artworld and world art (studies).
\end{abstract}

\section{Keywords}

Diaspora, Aesthetics, Philippine Art, Marcos Regime, Installation art, Cultural Center of the Philippines, Critical Theory, Globalization

\section{About the Author}

Clod Marlan Krister V. Yambao is an Assistant Professor at the Dept. of Art Studies, College of Arts and Letters, University of the Philippines Diliman. He has taught subjects in Western and non-Western aesthetics and art theory, contemporary cultures and the arts, popular culture, and gender issues in the arts in the undergraduate and graduate level. His 
academic interests include Philippine contemporary art, critical theory and contemporary art theory, Cultural Studies, globalization and modernity studies, installation art, and the avant-garde. A version of his undergraduate thesis, "Phallonoptic Malate: A Critical Analysis of Visual Culture, Performance and Space of Orosa Street and Bocobo Street, Malate, Manila" (in Filipino) was published in the Scopus-journal Humanities Diliman (Vol. 6, No.1 and 2 [2010]). Another essay titled "Philippine Installation Art from 1970 to 2008 as the Discourse of Philippine Postcolonial Avant-Garde" was published in the JATI Journal of Southeast Asian Studies 16 (2011), an international peer-reviewed journal based in University of Malaya, Kuala Lumpur, Malaysia. 


\section{FRAMING AESTHETICS AND THE GLOBE}

The process of globalization has obviously transformed the Philippine national life. It has opened the space for Filipinos to take the path of being transnational bodies-be it in political, economic or cultural terms. Other than the global inflow and outflow of cultural products and representations within and outside the national space, it is the Filipinos' experiential agencies and narratives where the process of the re-imagining of the globe occurs. The Filipinos' global mobility has stretched the discourse of the Philippine national life, as it becomes entangled within global engagements and transcultural encounters.

To quote a passage from the curatorial catalogues of the exhibit At Home and Abroad: 21 Filipino Contemporary Artists, about artists in the context of migration and diaspora:

... [Modern Filipino artists] have chosen the more difficult role in art, the role of the explorer, of the seeker of new ways. Though not all have discovered new relations and concepts in even their personal art, all are conscious for the search / The search is double pointed-one end forwards, towards new frontiers; the other backward, to rediscovery of lost horizons. (qtd. in Alvina et al. 15)

The Filipino artists' global mobility has pushed the limits of cultural and national boundaries in order to explore, engage and produce new forms of aesthetics, concepts and representations. Crucially, the Filipino artists' situated global experience in the production of aesthetics can be an organizing episteme that would allow us to elucidate the contexts of art and the global contemporary. I wish to call this as global "aestheticscapes." Critically, I appropriate Arjun Appadurai's theoretical assertions in an attempt to understand the political, economic and cultural conditions of global aesthetics. ${ }^{2}$ Central to this is his idea of global-scapes that allow people to stretch the tendencies and possibilities of living the global. The complexity of the global experience to shape and make identities, representations, technologies, ideas, and finances create and figure ecologies of social networks, infrastructural and epistemic zones of re-production, and dissemination of the global lives that are being metabolized, produced and consumed at the global scale. The confluence of the words aesthetics (which I define as an active and creative experiences as well as imaginations of making, acting and feeling) and Appadurai's "-scapes," which he defines as a "perspectival construct" implicated by global contextual situatedness, allows us to grasp across and stretch a vista of global profusion and amalgamation of aesthetics and world art (222). Broadly, by aesthetiscape, I mean the global discourses and production of aesthetics and art, and how these shape and make, enable and disenable the flow, production, circulation, interactions, and mediations of aesthetics, feelings, affects, emotions, imaginations, creativity and creative practices, experiences, artistic sources and expressions, and inspirations 
and influences. Informed by the complex global relationships in the sphere of art activities, the infrastructures of art, the shifting performative forces of the artworld and the aesthetic narratives and agencies of people in mobility, aestheticscapes provide a platform to articulate the intersections and narratives between art and globalization. Therefore, aestheticscapes are undergirded by: global transfers and mobilities, of free art and free markets, complex zones of exchanges, networks of encounters, ports of contacts of aesthetic perceptions, circuits of ideas utilized by artists' imagination and constructions, different politics of openings and openness, global closures and disclosures, and global artist network of socializations like international art grants and residencies, global nomadism of artists, scholarships, international biennales and triennales forums, conversations and conferences, circulation of online art information, and the global circulation of aesthetic knowledge intimating in general the wide context of global contemporaneities.

Crucially, aestheticscapes provide a platform to be aware of the body's global state and feelings of being, as well as its sense of the world. Through these examinations, aestheticscapes become an aesthetic inquiry and epistemic idiom that attempt to critically frame and engage the tensions and rhetorics of the local/ national/global, the colonial/postcolonial/neocolonial, globalism/globalization/ internationalism, the ever growing relationships and interactions in world art, and the globally expanding and shifting artworld, cultural experiences and discourses of contemporary globalization.

These contingencies and movements allow us to grasp and significantly to be critical of the rhetoric of universalizing categories (i.e., authenticity, originality, purity, nativity, structuralism) as well as the complex distinctions, hybridities, profusions, mixtures of cultures brought by the traces, flows, affinities, connections and blurrings of different geo and ethnoaesthetic exchanges and engagements as grounded politically and historically.

In 1936, the first Director of the New York Museum of Modern Art Alfred Barr made a chart of the origin of Cubism and Abstract Art (see fig. 1). 


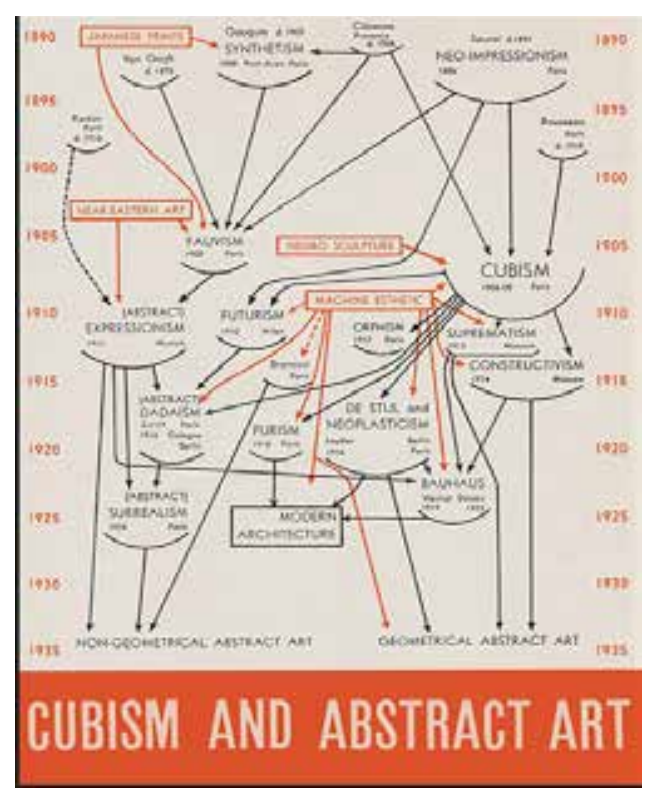

Fig. 1. Barr, Alfred. Cubism and Abstract Art. 1936. Musuem of Modern Art, New York.

In his exhibition, he created a map that illustrates the history and aesthetic genealogy, traces and permutations of Western modern art in his exhibit Cubism and Abstract Art. In general, the map alerts us to the aesthetic provenance and influence of "Western" modern art from different global locations. The chart shows how the celebrated "Western Modern Art" and its forms are aesthetically enmeshed by what at that time was imagined as the "other" namely, "Negro Sculpture," "Japanese Prints" and "Near-Eastern Aesthetic." These "non-Western" sources, highlighted in orange signify both recognition of aesthetic source, and at the same time its alterity from Western modern and formalist aesthetics. What this map interpellates in tagging these aesthetic/artistic movements is the aesthetic positions of power and the power of aesthetic positioning. As it recognizes the originary sources of these mentioned styles framed on geoaesthetic provenance, it also attempts to gesture towards an order of canon and othering that reiterates the hegemonizing narrative of Western modern art. This alterity is informed by the rhetoric of colonial modernity, orientalism and the "free world"/ internationalist doctrine of American imperialism extended into the valorization of "artistic freedom" made possible by avant-garde aesthetics which, through the advocacy of the New York School of intellectuals and artists, clustered around modernist critic Clement Greenberg, viewed abstract expressionism and other avant-garde art theories produced primarily in the United States since 1947 as the "end of art." 
This map shows us how the complexity of the epistemic life of aesthetic discourses may ramify relational and intersectional conditions with social categories such as race, gender, class, age, sexualities, and ethnicities in the larger scale of the globe. Furthermore, the modern art movements' global gestures of exchanges and influences situate and locate aesthetic productions and imaginations within the un/problematized coordinates of global power systems, histories and geographies. What is apparent in the condition of this contemporary globalization is that it gestures toward "openness"-of borders, ideas, economies, communications, information, and art. Consequently, this openness allows us to create more spaces and language of contacts, contracts, engagements, encounters, frictions, contaminations, exchanges and modes of struggles and dialectics. Doreen Massey underscores the social relationships and interactions in the moment and experience of global mobility:

If one moves in from satellite towards the globe, holding all those networks of social relations and movements and communication in one's head, then each place can be seen as a particular unique point of intersection. The uniqueness of place, or a locality, in other words, is constructed out of a particular interactions, and mutual articulations of social relations, social processes, experiences and understanding, in a situation of co-presence, but where a large proportions of those relations, experiences and understanding are actually constructed in a far larger scale that what we happen to define for that moment as the place itself, whether that be a street, a region, or even a continent. Instead then of thinking of places as areas within boundaries around, they can be imagined as articulated moments in the networks of relations and understandings. And this in turn allows a sense of place which is extraverted, which includes a consciousness of its links with the wider world, which integrates in the positive way the global and the local. (28)

While other globalists are seemingly affirmative and celebratory on the effect of globalizations and its ways of opening the conditions of possibilities, one is also invited to take a sharp and critical stance on this project and the condition of opening-up to the world. Arjun Appadurai's text is instrumental in the further understanding of global productions via the language of "disjunctiveness" and complexities, however, his assertions has to be taken with critical distance. The global "power geometry,"3 in the words of Massey, is not just about the creation of distinctive and unique cultural appropriations in the global village. Crucially, this "power geometry" touches the undeniable asymmetries and culture vulturism in the expansion of global powers that may transpose and dispose the lived experiences of people in global mobility. Most importantly, within the Third World, postcolonial, global south geographies and temporalities. As Homi K. Bhabha asserts in his reflection as to who owns the globe: "it shrinks for those who own it; for the displaced or dispossessed, the migrant or the refugee, no distance is more awesome than the few feet across borders and frontiers" (449). 
Bhabha's passage questions the politics of the globe and the political passage of the post colony in the global space. It highlights the asymmetry of power relations between and among the empires and the afterlife of its former colonies. Here, the diasporics are dispossessed of owning the globe, as if they owed the empire their entitlement to possess and/or be dispossessed.

Because "aesthetics is born as the discourse of the body," this is how the body also narrates our sensate lives, our perceptions of the world, and the situatedness of the body (Eagleton 229). Furthemore, as the body is affected by the context and conditions of globalization, aestheticscapes take globalization as a political project of activating the discourses of the body and its embodiments within temporal/ historical and spatial/geographic global experiences. Aestheticscapes allow us to feel the texture of the globe: its roughness and smoothness, its jolts and placidness, and its contingencies and its recalcitrance.

The experiences of the artist in global mobility initiate the global life of aesthetics. Artists in global mobility activate our emotions and senses to move towards global sympathies and shared-ness. Aestheticscapes create new modes of experiences that allow us to reveal the discourses of globalization; to see the breakdown of powers that operates and organizes our global lives, and figure new spaces of reorganizing the canons and hegemonies of culture and the arts. Aestheticscapes serve as the energy of the stickiness in the artists' engagements with the globe that provokes a friction of social and cultural relationships, within the spheres of our socio-aesthetic activities. Anna Lowenhaupt Tsing calls this friction as a "sticky engagement" which depicts the messiness of our global lives and as the consequence of global frictions. She argues that encountering globalization creates frictions:

A grip of our worldly encounter. . . enacted in a sticky materiality of our practical encounters. . . a study of global connections shows the grip of encounter: friction. A wheel turns because of its encounter with the surface of the road; spinning in the air it goes nowhere. Rubbing two sticks together produces heat and light; one stick alone is just a stick. As a metaphorical image, friction reminds us that heterogeneous and unequal encounters can lead to new arrangements of culture and power. (1)

Aestheticscapes locate, shape and make different languages and passageways toward global experience. Its role is to critically evoke and facilitate epistemic openings on temporal and geoaesthetic representations, productions, circulations and exchanges. It stretches our horizon to enable us to move across and beyond borders and terrains that encourage us to critically reimagine art and globalization. The hermeneutical texts of aesthetic production in the age of globalization may set the condition of remapping, reframing, reproblematization and reshifting the genealogies, histories, epistemologies of art as critical world aesthetics and world art.

Kritika Kultura 24 (2015): -235 
In this paper, I will look at how globalization gains currency among selected diasporic and migrant contemporary Filipino installation artists and their significations of their artworks as an exemplification of global "aestheticscapes." I will elucidate how globality (which is initially defined here as the condition of social mobility, inflow and outflow of capitals and global products, local-global tensions, nation-transnational and postnational issues, shifting identity politics, aesthetic multiplicities, and the like as a cultural consequence of the economic logic behind neoliberal imperialism) becomes a historical context and site of the aesthetic imagination and contemporary artistic productions of the Philippines, especially within the context of aestheticscapes as an utterance of "cultural citizenship." Martin Manalansan, who followed the assertions of anthropologists Aihwa Ong and Renato Rosaldo on the notion of cultural citizenship, provides a parameter that specifically elucidates this paper's discourses of the artists in global mobility and their installation art created at the Cultural Center of the Philippines (CCP). The CCP is a state-sponsored institutional apparatus that endorses, negotiates, deploys, and mythologizes the discourses and dialogics between nationalism and globalization, as realized in the utterances of the artists and the representations of the artworks. Their exhibits at the CCP gestures a kind of symbolic return which as Manalansan further asserts is a form of "return migration"4 or the "performative arena where the tensions and contradictions about space, nationhood, gender, sex, class, and citizenship unfold and play out" (62). Manalansan further elucidates the concept of cultural citizenship as the:

Scripts of belonging and performance of cultural filiation. These scripts in turn become part of the cultural capital, the nexus or medium through which returnees' ties to and investments in the nation are valued, assessed and understood. (64)

Finally, I will analyze the resurfacing hermeneutical text of their artwork; not just as indices of the artist and the artworks' cultural background, but as well as the (dis) enabling engagements of their global experiences to make and shape discourses of our postcolonial and Third World aesthetic methods, epistemic bodies of aesthetic knowledge, and strategies of global critiques and interventions.

The artworks of Filipino diasporic, migrant and mobile artists have addressed diverse issues from personal to collective struggles and narratives. I believe that these artistic agencies inform us of the cultural reflexivity/reflectivity of the critical and politically changing landscapes of Filipino artists across the globe within and/or without the nation. Their life-worlds, be it framed by families, neighbors, sphere of social activities, and institutional artworlds allow them to map their cultural positions. These social frames serve as orientating strategies and compass of Filipino artists. They also serve as a mode of survival, social interactions, and critical positions. 


\section{CONTEXT}

Colonialism has resulted in the diaspora of Filipino artists. Juan Luna, who produced the celebrated Spoliarium (1884), travelled and studied in Europe to further his academic training in painting. The Spoliarium is said to be an allegory of the Philippines in distress under the Spanish colonial period. Hidden in this romantic work is the political articulation of the ilustrados in Europe to realign the colony within the strengthening geopolitical formation of nationhood/statehood. This has been implicated by the epistemic movement of Enlightenment modernity in Europe through the agency of educated ilustrados who were able to articulate discourse of nationalist positions and consciousness. Rizal in his brindis toast hailed Luna as a "universal artist, a genius whose greatness transcend[ed] race, border and origin." After the Spanish colonialism, Modernist painter and American-trained Victorio Edades, awarded National Artist in 1976, stirred the Philippine art scene which was then dominated by classicist/academic tradition when he came back to the Philippines in 1928. His American colonial period painting, The Builders (1928) was acquired by the Marcoses and displayed at the CCP. The Builders was a timely contextualization in a regime that attempted to construct the nation through its Bagong Lipunan movement, as well as through the ease with which the regime privileged modernist avant-garde art.

Although the diasporic and migratory narratives of the preceding two visual artists necessitate a separate study, these examples may lead us to examine the earlier politics of globalization implicated by colonial migration and earlier projects of Enlightenment modernity. This could possibly show us how the artists in the time of critical narration of the nation explored the limits and possibilities of aesthetic and visual language as a tool of artistic enterprise, acquiescence and resistance to the dominant social and political forces. The accumulation of social experiences as migrant and diasporic workers, be it in the state of pain, struggle and celebration, negotiations, and artistic "compradorism" 5 is signified in their artwork. Their life narratives temporally situates the artist as a national body and nationally embodied via representation of the nation to the world and the world to nation based on its visions and revisions. Their hyphenated identities is crucial in enabling them to engage both within, without and outside the nation.

Art is a visible and temporal performance of packing and repacking experiential baggages; and the loading and unloading of affective, sociocultural burdens, and representations of people in transit. Surely, the baggage of acquiring and experiencing the globe, despite Doreen Massey's assertion, is not a neutral act. The provisions of the artists' as they move temporally and spatially become part of the global narrative and lived value/s of the artists. That is why Filipino-American artist Carlos Villa calls this value as utang (debt):

Kritika Kultura 24 (2015): -235

(C) Ateneo de Manila University

<http://kritikakultura.ateneo.net> 
Utang is a Filipino word for "tribute" or "what you owe" . . [T] here was a tone to it that carried an urgency; not to be taken lightly. . .Whether we are Asian-Americans or not, as we study each piece, regard and contemplate social histories as well as aesthetic issues, and whether it shows or not, we should remember these images are in themselves individual monuments about personal pride amidst a time of fierce xenophobic hostility. ..Every day that I think of those who come before me, I feel warmed from my utang. . . (ii)

The valuation of experience that is owed to one's pinagka-utangan (debtor) becomes a physical and symbolic exchange with history, culture, social relationships, and experiences. This is perhaps the affective leash that obliges the artist to pay back-priceless, no doubt, as the indebtedness comes "from within" (utang na $l o o b$ ), which no amount of physical or monetary value can pay back. The potency of payback reveals the person's kalagayan (condition) and ability to pay back in order to somewhat be in the state of being palagay ang loob (at peace).

Carlos Villa is a second-generation Filipino-American and a son of a first-wave labor migrant called "manong." These "manongs" arrived in the United States during the 1920s. Villa gained access and recognition in the American artworld in late 196os, which was the time when contemporary art was gaining legitimacy and consecration in the US as a reaction to modernist art. His series of installations made from feathers is just one of his artistic mediums as he also produces visual and performance art. His "feather" series sets an aesthetic tone of interculturalism by incorporating in his artwork the diverse materials, cultural objects and representations from ethnic, traditional and primitive cultural practices. His artistic production is also his strategy of showcasing the politics of multi-ethnicity in America, which is often projected as a melting pot of cultures. Fletcher further explains his artwork:

... [as an attempt] to understand his own cultural heritage-a complexity of Filipino traditions with its layered strains of Asian, African, Indian and Oceanic cultures, along with the influences of a Western artistic tradition-became over time an exercise in creating his own visual anthropology to represent his personal background, and in broader sense, the dynamics of true intercultural weaving. ("Carlos Villa: Poet of Visual Metaphor" 35)

The potency of Villa's earlier work was grounded in reimagining the ethnographic belief systems as multicultural-as-American art (see fig. 2). This is informed through Villa's participation and social interaction with African-American, AsianAmerican and Mexican-American communities during his formative years. 


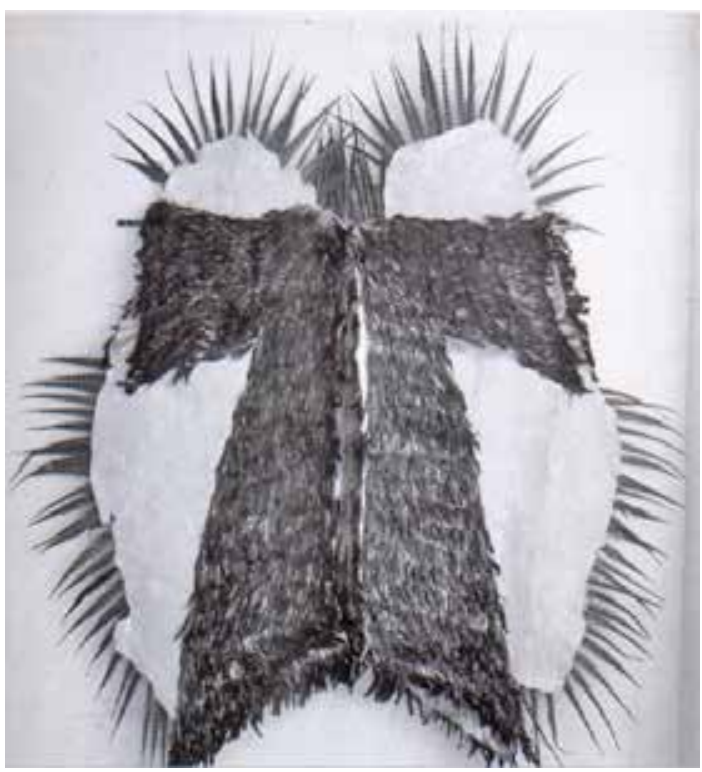

Fig. 2. Villa, Carlos. Black Feather Cloak. 1969. Mixed Media installation.

Villa recounts that he was invited by Raymundo Albano to exhibit his artworks at the Cultural Center of the Philippines. However, the plan did not push through because of several matters that might affect the logistical nature of his production, like the nature of the artwork as ephemeral and organic. Therefore, the artwork was prone to infestation, breakage, and fragmentation. The opportunity to push through in exhibiting in the country has never been realized.

Social context, agencies and aesthetic articulations are legitimate considerations when addressing the ideological and representational concerns of the artists' immediate location. While his work obviously echoes the representations of several Filipino significations and aesthetic hybridity from diverse cultural maps, Villa reimagines the possibility of mobile subjects and bodies as having multiple selves.

Artist David Medalla who moved to London to pursue his career in the mid196os, left several marks of artistic innovation in the country. He is known to have started the kinetic art movement in Europe in 196os. His series of Bubble Machines were exhibited at the CCP as part of the Fifties exhibition in 1971 (see fig. 3). He was recognized in the CCP as one of the important figure in Philippine art in 1950 s in the field of three-dimensional works. 


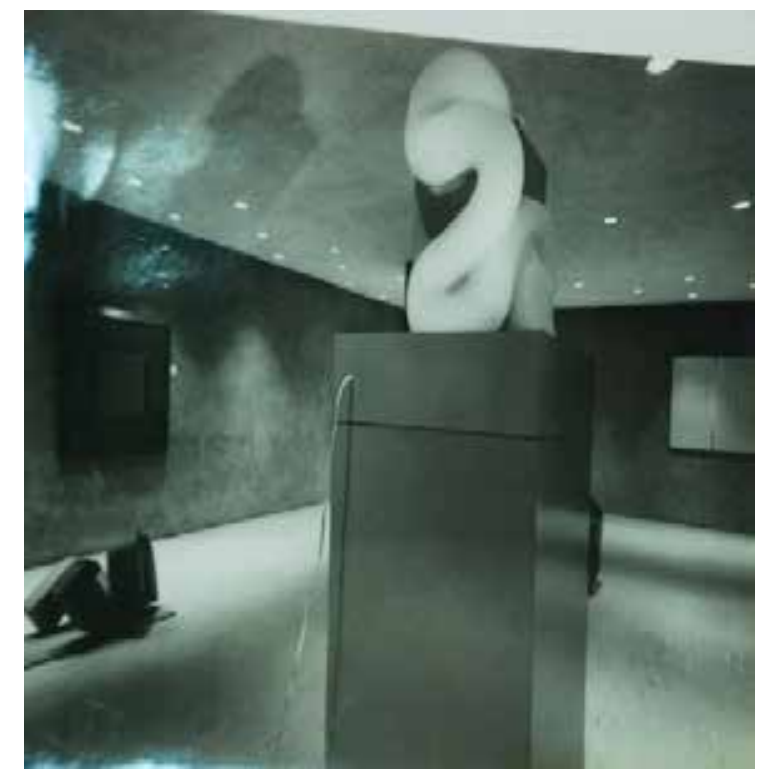

Fig. 3. Medalla, David. Bubble Machine. 1971. Kinetic installation. From the Fifties Exhibition. CCP.

We see through the works of the mentioned artists how the global arena implicates the textuality and textures of their artistry. Villa's work in his earlier years might have been dealing with the indigenist-primitive expressions, but its entirety cannot be strictly ascribed as Filipino. Rather, his artworks are products of visual and cultural appropriations from indigenous cultures all over the world-often from the most marginalized cultures. By doing so, he tries to weave the multi- or trans-ethnic imagination in his works, and we must remember that this constitutes a pressing political issue among peoples of diasporic origin in the United States.

On the other hand, Medalla's Bubble/Cloud Machines showcases a cosmopolitan/ internationalist aesthetic that is attuned to the most avant-garde elements of the Euro-American art scene. These elements gesture towards a Dadaist signification formed through a futurist sculpture that aesthetically activates the relationship among time, space and dynamic movement. This may undoubtedly have been a product of the intellectual and artistic ferment that he shared with foreign artists during his global residencies. Yet, his work should not entirely be a question of how much Filipino and/or Western his aesthetics are; rather, we can ask how he has influenced and intervened in the production of global art.

While an ideological positioning in terms of location is a necessary platform in fleshing out the identity politics and the nationalist belongings of these artworks, it is also productive to look at the condition of possibilities of positioning beyond the limit of geopolitical location. The "Philippines" here should be encountered 
not just as a signifier of origin and producer of static meaning that are attached to the fact or matter of Filipino-ness and the assumed constitutive language of Philippine art. Rather, it should also be intimated as a term of critical engagement, as an active field of intellectual and aesthetic inquiry, and as a site of our translative, transitive and performative epistemological practices. This strengthens the political determination of artists to visualize their art and enables their narratives of struggles to be visualized and articulated. Hence, the Philippines here serves as a strategic anchor to reveal and interrogate the power relations in the globe.

Despite diverse representations, the effort of the CCP to identify and give credit to Filipino artists who were making a name for themselves and causing waves on the global art scene became one of the CCP's inter/nationalist thrusts. The "Philippines" as a former site of origin of the diasporic artists becomes the trope and frame for recognizing the artist as well as a site of discourse, inquiry and engagement of aesthetics. This is of course slippery. Diasporic artists are deemed to be constructed here as a "gentrified other." Gentrified otherness is defined here as a matter of ambiguous positionality of the migrant artist-or any migrant workers-to be gentrified and acknowledged by the country only through the metrics of success, and the capacity to bring good narratives for the country or their adopted country, be it in the form of financial or symbolic capital. Other-ness, on the other hand, is defined as a feeling of alienation in the former and sponsored country of location, because of the struggle and the social otherness they have been experiencing in the various spaces where they migrated. Conversely, economic and political otherness can also occur from the originating country-which is often the reason why they leave the country. The index of recognition of any country is mostly determined by the system of international production, and success in an artist's circulation in a global artworld. In exchange, artists may also serve as instruments in the project to intensify the nation's imagination of the increasingly problematic term "world class-ness." The global initially validates the nation's aesthetic output before it is finally absorbed as "ours" or as part of the national narrative.

CCP stands here as the ambassador of the state in granting and acknowledging the achievement of the artist in the global arena. Furthermore, the artworks that are staged in the institutional site becomes the site/sight of not only the revelation of aesthetic and artistic text of the artists in diaspora, but at the same time, the endorsement of state nationalist discourse-the CCP's own interpellation of the artists as bagong bayani. This is despite the variegating commitment of the CCP to the Filipino artists in the diaspora, or in general the weak institutional commitment of the State to some migrant and diasporic workers abroad. However complex the issues are, the exchanges are symbiotic: an accumulation of the symbolic capital and recognition of home for the artists and the acknowledgement of the states' imagined nationalist positions, both in the local and the international level through the artists. Ana Labrador had something to say in the movement of the nation visà-vis the symbolic leash it creates among Filipino artists in diaspora: 
[R]enowned artists with international reputation somehow seem to lose their citizenship as they gain prominence; ironically, the greater the reputation, the more their followers become keen to locate them precisely in their country of origin. This is especially the case when the state agenda includes promoting the art to foster a sense of nationalist pride. (qtd. in Flores, "Missing Links Burned Bridges" 56-57 )

Moreover, diasporic Filipino artists are not the only ones entitled to represent the conditions of globality and the struggles of Filipinos in diaspora. Since globalization largely implicates the national social life of the country, it has also become a pressing concern among Philippine-based Filipino artists. Both work together not only in exploring such artistic and aesthetic texts, but also in informing both the local and the global artistic arena of national and global conditions.

The artists' social experience and sensibilities both in their new homeland and in their former home conditions them to further engage a broader sense of aesthetic issues and realms by occupying multiple and situated political positionalities. This is especially true when the presence of the Filipino body has its own urgent concern and from which the nation may be beyond it. This demands a strategy to reimagine their agency being located somewhere else, which is to say, "elsewhere." Chinese scholar Sau Ling C. Wong calls it denationalization. For her:

[I]t addresses the transnational concerns. . . advancing the ideas of contextualizing meanings, social relations and social actions and/of liberalizing the confines of social boarders, that cut across nation, gender, ethnicity, kinship, and social class in Asian American history. (7)

Denationalization is seen as a strategic positioning that allows artists to split and double their artistic selves, in order to unpack/repack the baggage of their nationalist embodiment towards a more situated locale, in which their social self is located. To echo Machida Margo in his explanation of the becoming of the artists in the migratory condition:

Amid the continual movement of people across national boundaries, diaspora itself is an inevitably plural "noun." Whose parameters are best viewed within the larger global frameworks. Marked by hybridity and continual renewal, the diasporic condition generates intrinsically multiple perspectives in visual art. In this polycentric vision, this proceeds from dialogic interaction, the realm of the visual functions as a principle interface between individuals, communities and cultures. (qtd. in Machida 44)

The political categories of identity and identification for Filipino artist in diaspora are complex, shifting, and arbitrary. Hence, the categories identity and identification shape the Filipino global ethnoscape into an ambivalent/ disavowed 
and often unself-conscious mass. For instance, identification as hyphenated (i.e. Filipino-Spanish, Filipino-American, Filipino-British, Filipino-French, FilipinoItalian, etc.) may be as much a matter of affect as of location (i.e. Filipino in America or Filipino in Europe). This recognition performatively provides weight to the aesthetic and artistic concerns of the artists and their own body politics. More so, these social interpellations have their own political limits and possibilities. The hyphenated identity is legally constricted as "immigrant," and the identification opens accommodations to any Filipinos in the diaspora and can also be a form of cultural identification.

The hyphenated has a load of legality through citizenship. This is clearly deployed among the second and third generation artists, or those who have been born in the new homeland, in which the category of Filipino-ness is arbitrarily identified via racial descent. Of course, the hyphenated identity of other Filipinos may performatively declare the identity of their location despite the legal, economic and familial permanence in the new homeland. Clearly, this declaration functions as a strategic political act in renewing their symbolic and affectional attachment to the Philippines as well as to their new country. In addition to the issues of geopolitics, not only do their attachments accommodate the hyphenated identities, they also differentiate from other Filipinos who do not yet have citizenship, and whose bodily presence is temporary within the foreign country. This is true among Filipino OFWs who have been burdened by the contract of temporality and job expiration, and thus their hyphenation can be cultural. ${ }^{7}$

There have been a lot of narratives about the condition of migrancy and resettlement. Our colonial history informs us of the global current of Filipino diaspora and migration. There were already claims of ethnic mobility from the Philippines to Mexico and America in the late- $16^{\text {th }}$ century due to the Galleon Trade ${ }^{8}$ to the rise of the ilustrados who were privileged to travel to Europe in the light of Enlightenment modernity during the mid-late $19^{\text {th }}$ Century, and to the pensionado scholars and the first wave of migrant workers to the US from the 1900s-1920s. Through the Philippines' alliance with the US during and after World War II, the redeployment of the national body politic through the outflow and inflow of Filipino bodies has been determined by immigration policies in the US and other developed countries. The migration during the Cold War period has largely implicated contour of postcolonial national life ${ }^{9}$ because of massive global neoliberal labor exportation in the opening of global market.

Filipino mass outflows further intensified during the Marcos period due to attractive economic opportunities abroad, and the unstable political and social climate in the country. Countries in Europe, America and Canada opened its doors for Filipino because of their new immigration policies; while the oil boom of the Middle East called for skilled and semiskilled workers. The term Overseas Filipino Workers (OFWs) gained currency as the country's "bagong bayani” or new heroes who send billion of dollars of remittances. As popular discourse puts it, their

Kritika Kultura 24 (2015): -235 
heroism derives from their courageous attempt to uplift the lives of their family members while working abroad despite the lack of State support.

Filipino artists are incorporated into the flows of this global economy, and even this has a Marcosian genealogy. The Marcos regime coined the term balikbayan as a program to capture the "return" of immigrant Filipino to their hometown, extended family or the nation-state in general. This strategic program treated the balikbayan not only as a denizen of the country but also as a tourist by "offering a combination of bargain airfares, tax breaks, and other incentives specifically attracting dollar-earning Filipinos" (Rafael 207). In President Aquino's period, the president hailed the migrant workers as bagong bayani or new heroes in fulfilling their role in national development. President Ramos, on the other hand, further reiterated the world-class service that Filipino manpower provides for the globe as part of his Philippines 2000 program. Administrations since then have continued to encourage Filipinos to migrate all over the world for jobs; labor being the country's primary global export. Currently, more than 10 percent of the Philippine population is categorized as part of the labor diaspora, and this figure is expected to balloon further as the global labor targets Filipinos because of our cheap labor. ${ }^{10}$ Former Gloria Macapagal Arroyo called the migrant and OFW heroes as the Overseas Filipino Investors. They are seen as the partners of the state to strengthen the economy of the Philippines via exportation of human labor and remittances.

The Filipinos in diaspora do not undergo an easy journey from their uprooting in the Philippines to resettle in their sponsored nation. The tropes and traps of migration often tell stories of struggle. It is also an exploration of "other/ed" worlds that inscribe the consciousness and social life of "being in place," especially in a highly racialized, class-based and feminized condition of global labor. The Filipino bodies' strategic position in cultural and political exclusion and/or assimilation to its sponsored home is often a struggle for visibility to declaim and reclaim the spaces of articulations, and to imagine and realize its artistic agency. Flores argues:

The dissolution of nation in favor of global market economy and society spawns its own crisis and so complicates the issue substantially... one realizes that the Philippines here and elsewhere has transformed our notions of "home" and "abroad," with its contemporary art changing the various worlds it inhabits with the nostalgia of recreating the homeland in the matrix of estrangements and affinity, entitlement and distance, rupture and retention. ("En Route" 19)

This amplifies the condition of diasporic Filipino artists and their global subjectivity. Through their installation art, they track the protean movement of the Filipino transnational body as signaled by the political trialectics of Filipinos: "being" transnational bodies, the nation-globe relations and their artistic representations in installation art. 
The Filipino migrant artist-couple Isabel and Alfredo Juan Aqulizan unfold the texture of affective longing for their origin-home (in the Philippines) and enfold their hopes of a new life in their sponsored home (in Australia). Their installation artworks are often characterized by a critical intimation with collected contemporary cultural objects; transforming their belongings as installation, and symbolically cathecting it with memories, sense of place and identities. Their artwork Project Belonging was part of the series of Danas: Palabas exhibit at the CCP curated by Patrick Flores in 2008 (see fig. 4). Danas is a five-exhibition series that attempts to "sense" the symptoms and manifestations of Philippine contemporary art as anchored through the expressions of avant-garde aesthetics as well as folk and popular expressions of the everyday life. Woven through the context of tropicality and the Filipinos' affective world views and sensibilities, the exhibit highlights works that create an aesthetic economy of experience articulated through the localmoral sensibilities based on the tropes of $\operatorname{sinsin}$ (intricacy), sapin (juxtaposition), diskarte (strategy), ginhawa (well-being), and palabas (performativity). The exhibit produces an inquiry in the complexity of Philippine art: its spatio-temporal situatedness, aesthetic dimensions and the exploration of Philippine art and beyond. The work of Isabel and Alfredo Aquilizan's migrant condition appears in the trope palabas (performativity) which the curator contextualizes in different texts and textures: as a spectacle, emotional output, outward inclination and leaving Palabas, is refashioned as "migration of Filipinos, a necessity that pressures them to resettle elsewhere and take on different impressions, acquire accents, feign cosmopolitanism, and pose as worldly as possible" (Flores, "Danas").

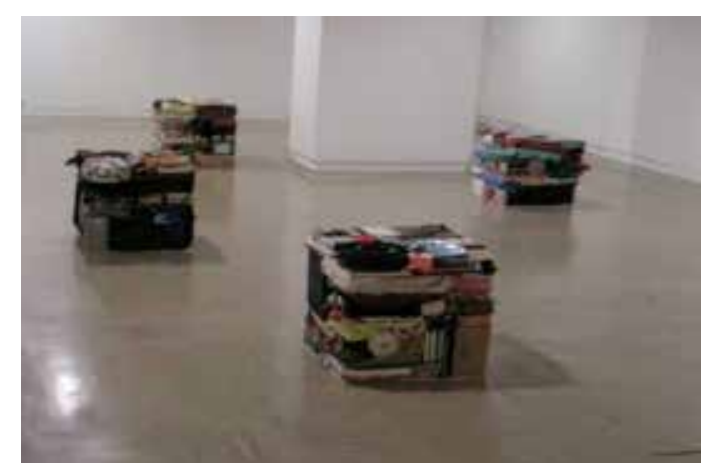

Fig. 4. Aquilizan, Afredo and Isabel. BE-longing: Last Thing, 2008. From the Danas exhibit. CCP Small Gallery.

The artists who migrated to Australia in 2002 transformed their personal belongings into installation art when they decided to leave the Philippines for Australia. The objects that were packed follow the contour of the container box that 
consisted of their children's toys, clothes, kitchen utensils, Christmas tree, friends' gifts, and other domestic materials.

According to the couple, their works embody the act and politics of collecting, often coming from the domestic and the quotidian: "A body of work created concerning domestic life and everyday experiences with particular emphasis on contemporary culture" (Flores, "Three Trilogy" 23). The works that were exhibited in Danas were personal objects that the artist-couple decided to leave in the country. They painstakingly transformed the to-be-left-behind objects as art forms. The enactment of the artist couple's art-making signifies the baggage of leaving: to decide what to leave behind, and what to bring with them materially and symbolically as part of their survival abroad. Flores in his curatorial note explains the work of the couple as:

A terminal scene in which the wrenching process of migration becomes poignant because it is caught between the anticipation of a beginning and a revision of origin or address, between art and life. Here migrants as agents are, on the one hand, disembodied in the site of exile, rendered present by their property but, on the other, are active senders of memorabilia from a dis-locale, suspended in the act of disposing and dispossessing.

("Danas")

According to Alfredo, the act of sorting out, of choosing what to bring and what not to bring, is in itself a painful enactment of leaving. The act is also a discriminatory sorting of affect, unpacking and repacking one's life carefully and deliberately-what is known in Pilipino as pagsinsin or "a certain delicate attention to the details of manner, method, or material."11 The engagement with personal belongings is always an act of ownership (pag-angkin). In this performative aspect, as Flores asserts in the work of the artists couple, artmaking becomes a danas of palabas which means both "appearance, inclination and intimation." This outwardness is always a conscious dialogue with ownership, and what seems to appear as one's own (kaangkinan).

The extent, condition, and capacity of the artist to "de-cathect" and "dis-possess" the objects of its affectual meanings through the enactment of leaving resurfaces the possessions with the notion of provisionary supplies (pabaon) and the provisional. Hence, in this act what is left is also part of its emotional load that is performed while in transit-the struggle to carry the baggage of Filipino transnational bodies as the means and modes of survival.

The ka-angkinan of this artwork at the CCP formalistically follows the technique derived from Hans Hofmann, a modernist painter ${ }^{12}$. His style of rendering the spatial depth and movement through the execution of color is called the "push and pull theory." Hoffman was influential in Aquilizans' formulation of their work, which inspired them to turn this two-dimensional art technique into a volumetric three-dimensional art form. Each and every aspect of this layered and vibrantly 
colored artwork, composed of the artist couples' personal objects, secreted the ideas that sent signals: of being departed and departing; or of being torn apart. Alfredo and Isabel Aquilizan's art as (dis)possession relays the complex message and stories of global diasporic departures and arrivals.

Consequently, the Danas exhibit at the CCP was paralleled with another exhibit at the Sydney Biennale in 2008. ${ }^{13}$ The artists exhibited in Sydney the belongings that they decided to carry along the way to Australia. The two parallel exhibits were a long distance affair where the body was in between (or perhaps, split and doubled) the former home and the home-to-be. This exhibit cues us into the artists prefiguring and re-configuring the past and the presence of experience. As the bodies become mobile, belongings signify the pain and distress (algos) of homecoming (nostos), a dis-ease for the "nostalgia for the future" that was to belong to the world and to become a being in the world, with their own attribution and rightful place. This artwork therefore rendered the act of finding and looking for the home, and the construction and shaping of the home materially, emotionally, economically, politically, culturally, and psychically as critical (of) nostalgia.

While the primary locus of the artworks of the Aquilizans was the collection of experiential and affectual transcriptions of migrant performativities, Jose Tence Ruiz's work Erding Erdrayb at ang Kanyang Palasyong Agaw-Tanaw (1981) informs the viewer of the post-OFW condition of a migrant worker (see fig. 5). Tence Ruiz's Erding Erdrayb at ang Kanyang Palasyong Agaw-Tanaw (Driver Erding and His Now-You-See-It-Now-You-Don't Palace) became part of the exhibit The Jeepney at Bulwagang Juan Luna in March 1986. This exhibit surveys the jeepney as art, as a popular part of our quotidian Filipino culture and life, and as an expression of Filipino craftsmanship and design. "The jeepney is not only integral in commuting mass life of the FIlipino. The Jeepney also shapes the significations and exercises of power among social classes, races, genders and histories. Being a residue of American colonial war modenity, the Filipino jeepney's infrastracture signify oir hybrid cultures, our alterities, our glocalities, our histories of making do, and our strategies of survival and livelihood using our local and moral aesthetic sensibilities and expressions of the everyday life. 


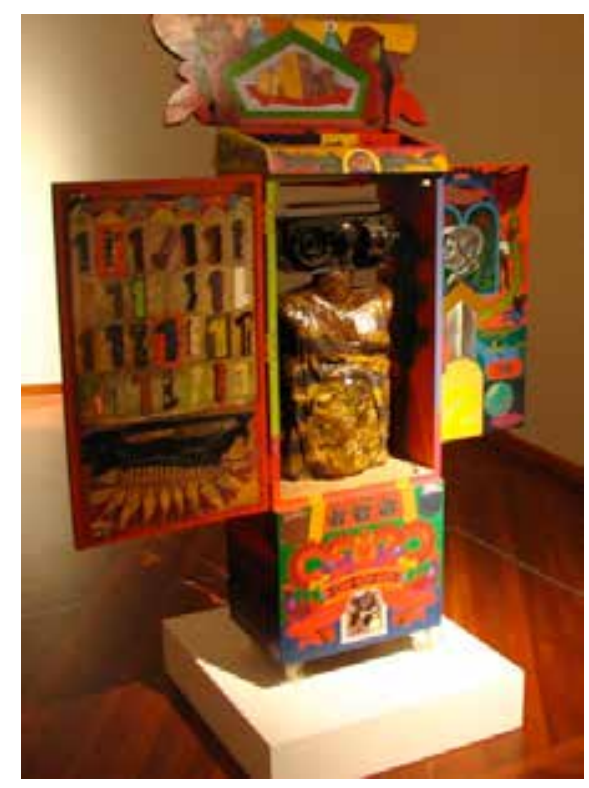

FIG. 5. Tence-Ruiz, Jose. Erding Erdrayb at ang kanyang Palasyong Agaw Tanaw. 1981. Mixed media installation. Exhibited during the 1988 Thirteen Artists Awards, CCP Main Gallery.

Taking its context from the social and economic conditions engendered by the labor export market of the government, and the surplus economy, this cabinet shaped work hypersignifies its cathexis of diasporic labor via the passage written on its headboard: "Katas ng Saudi." The term is a popular sign found among passenger jeepneys-which are often the primary investment of many returning OFWs from the Middle East.

In Erding Erdrayb at ang Kanyang Palasyong Agaw-Tanaw, the signage claims its Filipino transnational labor as a form of affective investment eked out from the site that was the labor-intensive, and distant place of work, Saudi Arabia. His installation, according to Alice Guillermo, signifies the hard work of Filipino migrant workers:

From the visual clues, one gathers that Driver Erding bought his jeepney out of the earnings of his overseas stint, a popular expression for such substantial purchase being Katas ng Saudi, the concentrated extract of blood, sweat, and tears wrung out of the experience of the migrant worker. (21)

Erding Erdrayb's signage "Katas ng Saudi"14 reified the labor, blood and sweat of an OFW into an object of improving their lives in the Philippines through the jeepney. The jeepney becomes an icon of economic living, and invested of dignity in one's own country as the product of one who is earning (kumikita) for the family's 
subsistence, so that others need no longer be displaced and alienated by global labor. Erding here drives his own destiny despite the economic crisis in the home country, and mandates the directions of ginhawa in driving the destination of his anticipatedly positive future in the midst of the Philippines' onerous realities.

Erding Erdrayb at ang kanyang Palasyong Agaw Tanaw valorizes how the hardearned money from abroad can be transformed into a mobile trophy and a form of kabuhayan. It was also because of kabuhayan that Tence Ruiz, despite his emerging artistic recognition in the Philippines, chose to leave the country for Singapore as an editorial graphic artist from 1988- 1995.

In 2003, Ruiz was commissioned as one of the set designers for the CCP's performing art production titled NeoFilipino: Balikbayan with Ballet Philippines. The event was a collaboration of local and foreign dance choreographers and multi-media artists. More than creating a set design, his work was also staged as an installation. Set as a mobile work, his set design was composed of a series of gargantuan "dice" made out of paper boxes. The big dice were intimated by the choreographed performance of the Ballet Philippines as they came out from these boxes. Ruiz collaborated with local "balikbayan" choreographers like FilipinoCanadian Alvin Erasga Tolentino and Filipino-Irish-American Kristin Jackson to show how the performance and his set design would conceive the new in NeoFilipino, which was signaled by balikbayans and the migrant conditions of the country.

By sharing the sentiments and experiences of global mobility, the collaborative work transpired to reshape the contour of Filipino-ness by affixing the prefix "neo-" in their works. This gave the signal that the neo- in Filipino was fueled by the ongoing phenomena of the dispersal and disintegration of Filipino bodies all over the installative works. This allows the choreographers/set designers to imagine a new community of Filipino relations at home and abroad, who speak with a double consciousness - a collaboration proposed as an "ethnoscapic" and "ethnoscopic" cartography of Filipino subjectivities around the world. The dice played a big role in marking out the hopes of Filipino migrants and diasporics as a taya (gamble). It cues the audience of the Filipino's putting a stake to their flight at every moment, and the conditions of their destination where security is governed by the game of fate-pagtataya.

Lyra Garcellano, although not a migrant and diasporic Filipina artist, tackles in her works the condition of migration and diaspora. She has stated that the moment she held a passport, it subjected her Filipina body to the politics of movement and the mobility of globalization. Furthermore, her temporary travels abroad through international grants and exhibits resulted in her efforts to raise public consciousness about migration issues-issues that came out of her own personal experiences, as well as those of her families and friends who already left for other countries, which allowed her to encounter and engage with their personal experience as migrants. 
Her artwork Stilled Life, ${ }^{15}$ was exhibited at the CCP during Sungdu-an National 2004 (see fig. 6).

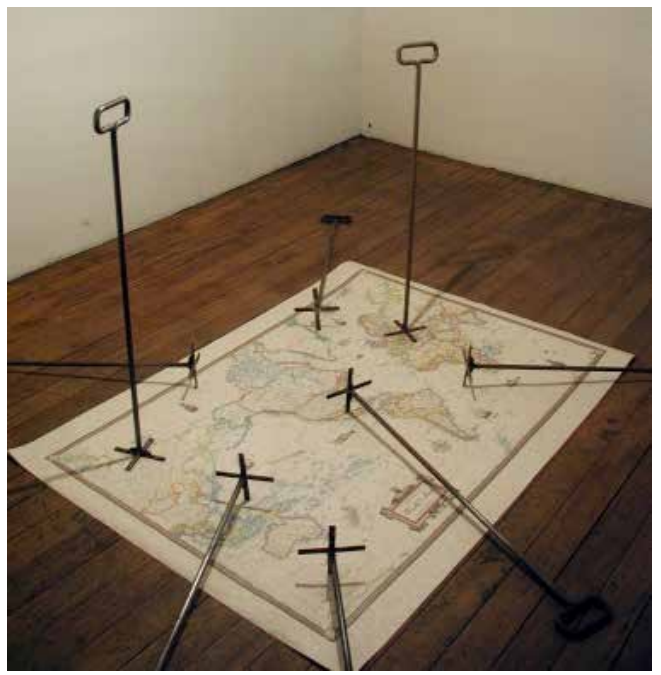

Fig. 6. Garcellano, Lyra. Stilled Life. 2003. Installation art. CCP Small Gallery

The exhibit Sung-duan, which is derived from a Waray word means mutual influences and confluence, reframes the notion of the "local" as it encounters issues of nation and globalization, the confluence of the young, new and the not new, and the possible and the beyond of Philippine art as recreated by young artists and new forms of art. The curator examines the notion of "nation," its myths, imaginations and realpolitiks and how these are articulated in the works of young Filipino artists. In this exhibit, the nation here is activated as a relflexive and reflective dialogue with the terms and life of globalization, history, the now, and its modes of exchanges. Stilled Life represents a critique to the post 9/11 conditions in the US. She reveals the political economic intervention of the Group of 8 to the world, specifically directing this critique to the G8 Summit's New World Order, perpetrated by the eight powerful nations in determining the global life of mobile bodies through immigration policies, intensified surveillance, global security and global political economic policies that promoted the othering of races.

\section{Curator of Sugndu-an 3 NCR Imelda Cajipe-Endaya explains:}

.. .Garcellano continues a path of conceptual inquiry into world politics and Philippine diaspora, which has phenomenally grown as an indispensable element in the economic survival of the country. "Stilled Life" is a cerebral imaging of the powers that rule today. A classic world map is laid on the floor where eight pieces of branding iron are arranged 
over it. These signify the Group of Eight nations in summit which decide policy issues such as immigration and globalization. The branding iron cast shadows of crosses. Thus alluding to a colonial past tied up to a history of colonial conquest. (29)

The post-9/11 period becomes the artist's trope that rearticulates the asymmetry of global power relations that racialize mobile bodies across the globe. Although positioned from the origin country, she takes off from the experience of migration coming from the narratives and stories of her loved ones. Stilled Life maps a mode of re-viewing the world from the perspective of a Filipina artist, especially in times where globalization has not only racialized socio-political relations, but also feminized global labor. Furthermore, she shows in her works how the old order's routes of globalization, and the contemporary geometries of global powers "cartographized" the fate of the First World and Third World's future destiny and destination.

Lyra Garcellano's views on her art, diaspora and globalization can be gleaned in her initial proposal for Stilled Life at the Sungduan 2003 exhibit:

I'm aware of what's going on, but I always think I'm a data constructor not a data researcher. In "Perishable Goods" I take a potshot on how the Philippine exodus can be attributed to the fact that the Philippines' main export are human beings. In Stilled life I look at the power play involved in global summits where the whole world awaits monumental decisions by a powerful few who provide the template on how the rest of the world should live. This is not recent phenomena; decisions have been made by a few just like 400 or so years ago. (qtd. in Cajipe- Endaya 41)

Migration has been one of the major implications of globalization and are currently being considered as "world historical event of late modernity" (Hall in Machida 195). The artwork of Filipino artists like Garcellano's response to global mobility and attempt to represent the peripatetic social life of Filipinos all over the world who are forced to engage with globalization makes art as a potent aesthetic tool to interrogate global hegemony. Garcellano articulates her encounter with the globe and the nation by creating diverse sets of representation of global political economy. Machida asserts:

Art produced under the migratory condition illuminates an intricate interplay between the global and local, in which the trajectories it frames are often considerably more complicated than those suggested by the standard accounts of migration, settlement and assimilation that envision a one-way passage between a country of origin and point of settlement. (195) 
At this point, the CCP served as the locus of texts and the installation artists as interlocutors of the global experiences of our kababayan at home and abroad. The CCP's national and institutional projects of congealing the nation, despite the disintegration of the national body politics, as seen from the dispersion Filipino bodies including artists all over the world, render the artist as a cultural agent of reconstructing and retransforming the representations of the national-global discourses.

Undeniably, the inevitable peripatetic itinerancies of the Filipino artists have allowed themselves to evolve and stretch the tendencies of viewing the world and reconfiguring their aesthetic worldviews. This is an opportunity to come up with newness through different points and zones of contacts. The amalgamated cultures and texts that they have encountered as they go through the hard passage of emotional and physical resettlement as being in the world pagpopook ng sarili sa mundo or palagay ang loob. Global "aestheticscapes," in which the scale and global landscape of aesthetics production are circulated and acquired by the artists through their exposure and zones of contact with the rest of the world, are platforms of reshaping aesthetic positionalities. Diasporic artists continuously explore the limits of articulating their dispositions at home and abroad as its in-betweens in order to continuously natalize the visibility of their transnational bodies and push the possibilities of speaking to the world. What the artists convey in their installation artworks is the act of locating newness and retranslating it through the different visual and affective aesthetic language. The artists resurface and reinterpret their personal and social lives as mediated and negotiated by both the local and global imagining. It renders the global social experiences and aesthetic acquisition as a potent armature of making and reshaping aesthetic and agential identities and rearticulating both the political life and the imagination of the local and the global. The "aestheticscape" therefore provides a platform of hybridized aesthetic production while artists ambivalently and liminally perform their double consciousness, their denationalization, and their critical nostalgia.

Carlos Villa, despite the ambivalent siting of home-ness, situates in America the bleak possibility of returning home, owing the nation an utang na loob for making a platform of identity politics and multiculturalism to pay the debt of being a migrant. Medalla, who continuously makes waves as cosmopolitan avant-garde artist, who pushes the limits of nationalist identity politics, and whose work nonetheless goes home as a balikbayan, render the absence of Filipino signification in his work more present. The Aquilizans collect not only objects, but also narratives that articulate the social conditions of Filipinos elsewhere by keeping them posted through their installation works of different social and affectual values. Jose Tence Ruiz's former condition as a migrant worker in Singapore presents a wide range of aesthetic ideas, from the alienation and aspirations of migrant labor, to staking a claim through the opportunities afforded by the global diaspora. Lastly, Lyra Garcellano, who despite not being a migrant worker, absorbs the condition of migration through the diasporic narratives of her loved ones, and transcoded her own passport into an indicator of 
global travel. The mentioned artists mapped through their installation arts the textures and topographies of the struggle of being a Filipino migrant, diasporic, mobile and subjected to the rules of global labor export. They visualize and articulate the fate/ faith, and destiny/destination of the postcolony by de/re-worlding the globe.

These artists interrupt the often celebratory textualities of globalization by being critical, and assert the narratives of their struggle, against globalization's effects to themselves, their communities, and their imagined nation. They transform the lived experiences of their bodies, spaces, transits, memories, and social relations as aesthetic texts to make sense of the globe. The complexity of their return by exhibiting at the $\mathrm{CCP}$ also re-present the field of their global experiences as well as their cultural capital. Their transit and transient experiences and works reveal that cultural citizenship is reflective and reflexive of positions in the global cultural spheres.

Filipino migrants, diasporics and mobile artists complicate the borders of national and global signification. This strategic positionality allowed their agential voices in both the global and national positions to be asserted, articulated and envisioned. These artists unpacked and repacked the baggage of transnational conditions through the hybridization of global aesthetic sensibilities. It has been amalgamated through the form of iconic cultural representations anchored on ambivalence, disavowal and the reiteration of pragmatic life concerns. Their condition has not only become a means of exploring new aesthetic terrains; it has also served as a foundation of their own re-settlement elsewhere.

The global subjectivities of artists rearrange, share and redeploy the constellations of seeing the world and ergo activates the feelings and emotions as transformative and interventive stakeholders of our global futures. What is then necessary in the seemingly inevitable openness, global interconnectedness, multiplicities, and movements is to assert how aestheticscape can propose an imagination of the world in the global scale. Aestheticscapes hope to expand the field of the discourse of world art and aesthetic. It provides engaged experience to our sensate lives that reiterates and trains our shared aspiration for sympathies, the reinforcements of identities within and without the nations. It encourages an aesthetic praxis that recognizes differences, distinctions and diversities on the one hand, and the exchanges, sharing, gathering, and permutations on the other. It opens the conditions of possibilities of creating political imaginations and interventions in the contemporary transit lives of people, arts and culture. Global aestheticscapes stretch our imaginations across and beyond possibilities of ontologically and politically reimagining, and redreaming the situatedness of what it feels like to be in the world or what the world means, does and senses. 


\section{Notes:}

1 My usage of the term aestheticscapes initially appeared in my article "Philippine Installation Art from 1970 to 2008 as the Discourse of Philippine Postcolonial Avant-Garde." JATI Journal of Southeast Asian Studies (16 [2011]), University of Malaya, Kuala Lumpur, Malaysia. This article is a lengthy and full theoretical exploration of the term.

2 Arjun Appadurai's "Disjuncture and Difference in the Global Cultural Economy" tackles the debate between homogenization and heterogenization of culture in the sphere of globalization. He considers the political, the economic and the cultural spheres in the making and shaping of global subjectivities and the complex movements of capitals, technologies, financies, ideas, ideologies, and identities in the ever-expanding landscape of global interactions and amalgamations of culture. He employs "-scapes" "to indicate first of all that they are not objectively given relations which look the same from every angle of visions... inflected very much by historical, lingustic and political sitautedness of different sorts of actors: nation-states, multinationals, diasporic communities, as well as sub-national groupings and movements..." (222). He proposes to understand globality and its life via an elucidation of the term "global -scape." He mentions fives "-scape" that he thinks is crucial in an attempt to debunk the old models of thinking about globalizations such us center-periphery, global-local, push-and pull and the like. The five are: ethnoscapes, mediascapes, financescapes, ideoscapes, and technoscapes. These are considered as complex and complicated movements of identities/ ethnicities, media, finances, ideas, technologies, respectively. See Appadurai (1990) for more theoretical explications of the global-scapes.

3 Massey describes power geometry as the complex global relationships, flows and interconnections of individual, social groups and cultures and the context of "power in relation to the flows and the movement." She recognizes the enabling and disenabling, and limits and possibilities of the powers of global flow of people as well as the situatedness of these movements.

4 To situate "aesthetiscapes" as a material and experiential condition, I am strategically anchoring this study to the compelling proposition of Martin Manalansan's performative notion of "returm migration." See Manalansan (2014) for his compelling study on return migration of Filipino-Americans to the Philippine Return migration resonates the meanings and representations of the materials that I wish to demonstrate in this paper. Aside from these specificities, further studies should be done in order to stretch the limits and possibilities of global "aesthetiscapes" by looking at other forms of the global life of aesthetics in its transit, flows, movements, circulations, exchanges, and productions.

5 See Appiah (1991) for the theoretical discussion of the term "comprador intelligentsia." They are considered to be the traders of knowledge and educated via western training. This subjectivity mediates the languages and representations of the globe to the local and vice versa. In writing about the 
experience of intellectual exchange between the postcolony and the former colonizers in Africa, he shares:

Postcolonial intellectuals in Africa...are almost entirely dependent of their support of their institutions: The African university, an institution of whose intellectual life is overwhelmingly constituted as Western, and the Euro- American publisher and reader. Even when these writers seek to escape the West-as Ngugi Wa Thiong'o did in attempting to construct a Kikuyu peasant drama-their theories of their situation are irreducible informed by their Euro- American formation. Ngugi's conception of the writer's potential in politics is essentially that of the avant-garde, of left modernism. (63)

6 I wish to acknowledge the contribution of my colleague Rolando Esteban who provided substantial ideas in the development of the terms in one of our coffee conversations.

7 Here I also want to add Vicente Rafael's observation on the global movement of the Filipinos. See Rafael (2008) for his definition of the balikbayan as an invented category of immigrant Filipinos who periodically visit the motherland. "Being a balikbayan depends on one's permanent residence abroad. It means that one lives somewhere else and that one's appearance in the Philippines is temporary and intermittent" (206). On one hand, OFWs is described by Rafael as "who are employed as contractual basis or for. . . those who return from working temporary jobs" outside of the country.

8 See Mercene (2007) for his arguments on the narrative of the early diaspora and migration of the Filipinos to the US.

9 In the United States, the demography of Filipino immigrating to the US changed due to the Immigration and Nationality Act of 1965. This has allowed Filipinos in the US to selectively invite and petition their skilled relatives. The rest of the Filipinos were allowed depending on its occupational skills. Immigration Reform Act of 1990 has allowed Filipino World War II veterans to become official US citizens. These policies have attracted thousands of Filipinos to migrate in the US.

10 The estimate was based on the information gathered by Commission of Filipino Overseas as of Dec. 2012. Web. 12 Jan. 2013.

11 See Flores (2004) for the complete curatorial note on Danas exhibit at the Cultural Center of the Philippines. Curatorial note exhibit at the Cultural Center of the Philillpines.

12 The artist was also the mentor of modernist action painter Jackson Pollock at the Art Students League in New York.

13 This information was gathered through Facebook conversations with the artist Alfredo Aquilizan on 21 July 2011.

14 "Katas ng Saudi" means the juice or sweat extracted from Saudi. The term serves as a metaphor of the product of hardwork of Filipino Overseas Workers in Saudi. 
15 Lyra Garcellano's "Stilled Life" was first exhibited in the Sungdu-an 3/NCR"3 at the Pasig City Museum on 12 Aug. to Dec. 2003 and curated by Imelda Cajipe-Endaya. The work was also part of the Sungdu-an National exhibited at the Cultural Center of the Philippines on 17 Feb. to 26 Mar. 2004 and was curated by Patrick Flores. 


\section{Works Cited}

Alvina, Corazon. Introduction. At Home and Abroad: 21 Filipino Contemporary Artists. San Francisco: Asian Art Museum of San Francisco, 1998. 15. Print.

Appiah, Anthony Kwame. "Is the Post in Postcolonial the Post in Postmodernism?" Critical Inquiry 17.2 (1991): 336-357. Print.

Appadurai, Arjun. "Disjuncture and Difference in the Global Cultural Economy." The Cultural Studies Reader. Ed. Simon During. London: Routledge, 1990. 220- 232. Print.

Cajipe-Endaya, Imelda. Sungdu-an/NCR *3 Making the Local. Manila: National Commission for the Culture and the Arts, 2003.

Flores, Patrick. "En Route." Transit: A Quarterly of Art Discussion 1.3 (1999): 19. Quezon City: Creative Collective. Print.

--.. "Danas." Curator Note for Danas: Palabas Exhibition. Pasay: Cultural Center of the Philippines, 2003. Print.

--.. “Three Trilogy Triennial” Transit: A Quarterly of Art Discussion 1.3 (1999): 14- 18. Quezon City: Creative Collective. Print.

--.. "Missing Links, Burned Bridges: The Art of the 7os." Pananaw 2: Philippine Journal of Visual Art. Manila: National Commission for Culture and the Arts, 1998. Print.

Eagleton, Terry. "The Ideology of the Aesthetic." Poetics Today 9.2 (1988): 327-338. JSTOR. Web. 20 Aug. 2012.

Floro, Mercene. Manila Men in the New World. Quezon City: U of the Philippines P, 2007. Print.

Guillermo, Alice. "Processes of Change: Jose Tence Ruiz." Image to Meaning: Essays on Philippine Art. Quezon City: Ateneo de Manila UP, 2001. 17- 26. Print.

Kwon, Miwon. One Place After Another, Site Specific and Locational Identity. Cambridge: MITP, 2004. Print.

Manalansan IV, Martin. "Performing Elusive Homecomings: Mobility, Embodiment, and Diasporic Filipino Youth." Kritika Kultura 23 (2014): 6o-77. Web. 20 Nov. 2014.

Massey, Doreen. “A Global Sense of Place." Marxism Today 38 (1991): 24-29. Web. 13 Nov. 2013.

--.. "Power Geometry and a Progressive Sense of Place." Mapping the Future: Local Culture, Global Change. Eds. John Bird et al. London: Routledge, 1993. 59- 69. Print.

Machida, Margo. "A Play of Positionalities." Unsettled Vision: Contemporary Asian American Artists and the Social Imaginary. London: Duke UP, 2008.17- 56. Print.

Rafael, Vicente. "Your Grief is Our Gossip: Overseas Filipinos and Other Spectral Presences." White Love and Other Events in Filipino History. Quezon City: Ateneo de Manila UP, 2008. 204- 277. Print.

Tsing, Anna Lowenhaupt. "Introduction." Friction: An Ethnography of Global Connection. New York: Princeton UP, 2004. 1-9. Print.

Villa, Carlos. "Forms of Utang: Payback and Tribute in Filipino." Asian American Art A History, 1850-1970. Stanford: Stanford UP, 2008. ii-iv Print. 
Zhou, Ming and Gatewood, James. "Introduction. Revisiting Contemporary Asian America" Contemporary Asian America: A Multidisciplinary Reader. New York UP, 200o. 1-48. Print.

\section{Photo Credits:}

Figure 1. Barr, Alfred. Cubism and Abstract Art. 1936. MOMA: Inventing Abstraction 1910-1925. Web. May 32014.

Figure 2. Ramirez, Veronica Esposo. 2008. Post-colonial Diasporic Conditions and its Effect on the Aesthetics of Filipino-American Contemporary Visual Arts c. 1980 to 2005 in California. MA Art History thesis. Quezon City: University of the Philippines-Diliman, Unpublished.

Figure 3. Cultural Center of the Philippines Library archive. May 11, 2010. Print.

Figure 4: Cultural Center of the Philippines Library archive. May 11, 2010. Print.

Figure 5. Personal copy of the artist.

Figure 6. Personal copy of the artist. 